\title{
Det cerlige jordartskort - frister ikke til cirkelslutninger!
}

\section{Af Troels V. Østergaard}

Jordartskortet - som viser, hvilke jordarter der ligger under muldlaget - er meget brugt og findes i mange geografibøger. En af de ting, som fremgår meget tydeligt af kortet, er den såkaldte "Hovedopholdslinie", der skulle være grænsen for isens udbredelse i sidste istid.

Min skepsis overfor jordartskortet blev vakt meget tidligt. Som ganske ung student var jeg assistent for statsgeolog på DGU (Danmarks Geologiske Undersøgelse) Helge Gry og karterede i Nordjylland. På en af de aftener, hvor vi sad på hotellet og skulle have tiden til at gå til sengetid, fortalte han anekdoter fra livet på DGU.

\section{Sand er sand}

Én af dem var, at når man så på de originale karteringskort, var der meget stor usikkerhed om, hvor "Hovedopholdslinien" egentlig skulle løbe. Så man på kort, hvor den karterende havde bevæget sig mod vest, lå den meget længere mod vest, end på nabokort, hvor den karterende var kommet fra vest og havde arbejdet sig østpå.

Forklaringen er den enkle, at sand er sand. Har man gået på hedesletten og har karteret hedeslettesand, bliver man ved med at kalde sandet hedeslettesand, indtil man pludselig opdager, at nu må det være smeltevandssand, for nu må man have passeret "Hovedopholdslinien". Og tilsvarende fortsætter man med smeltevandssand, selvom man er kommet vest for "Hovedopholdslinien". Det er jo ikke alle steder, den er lige synlig i terrænet.

\section{"Extramarginale aflejringer"}

I forbindelse med diskussionerne omkring bogen "Danmarks Geologiske Seværdigheder" (Politikens Forlag, 2003) er det gået op for mig, hvilken sakrosankt stilling "Hovedopholdslinien" har, og at jordartskortet har en meget stor del af æren/skylden for det. Der er ikke det menneske i dette land, som ikke på et eller andet tidspunkt er blevet præsenteret for jordartskortet, hvor billedet af "7-tallet" ("Hovedopholdslinien", red.) i Jylland har brændt sig fast i bevidstheden.

Jeg fik derfor lyst til at se lidt nærmere

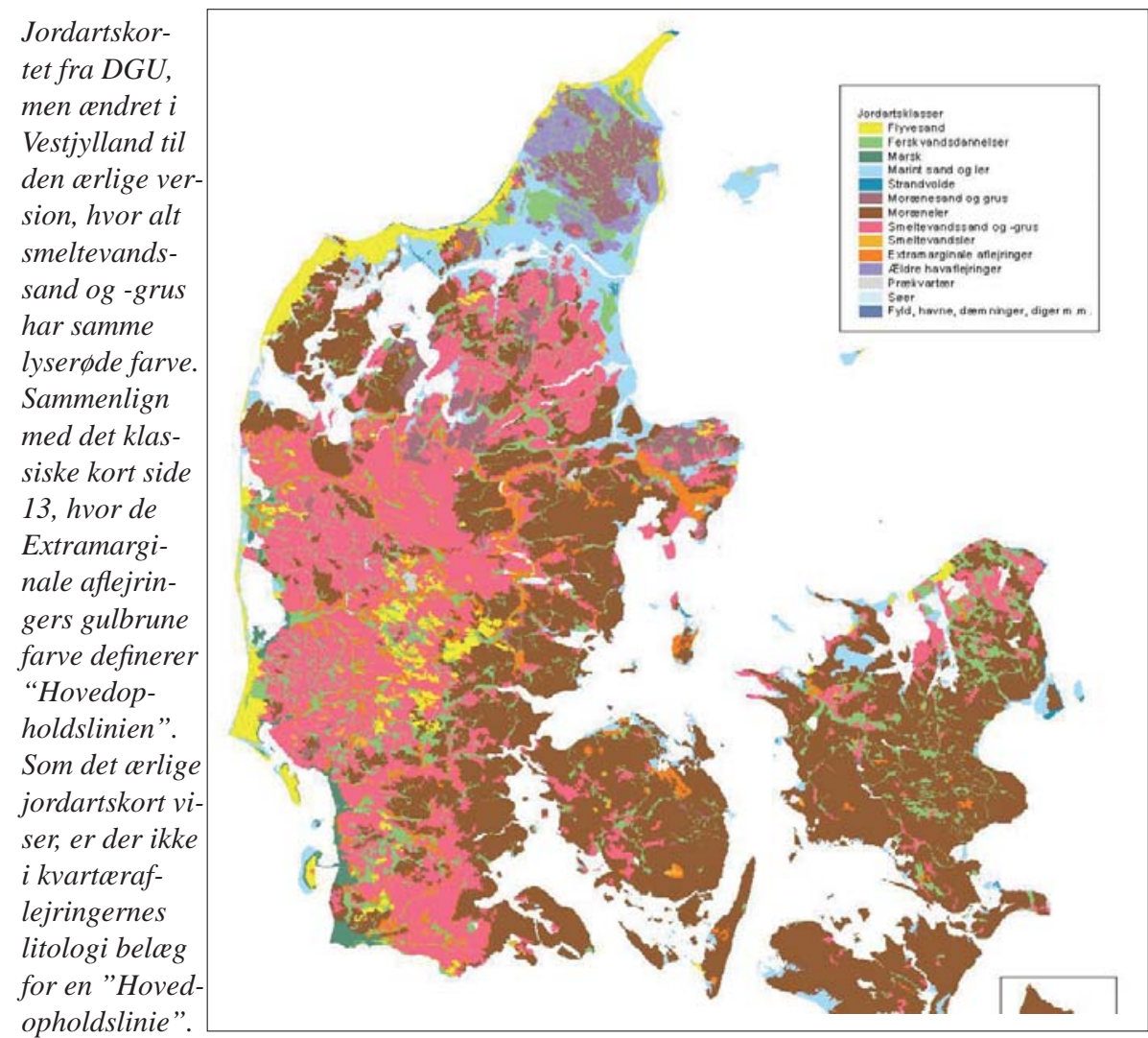

på, hvad kortet egentlig viser. Og stor var min forbavselse, da det gik op for mig, at den gulbrune farve, der definerer "7-tallet" mod vest, viser "extramarginale aflejringer", altså dannelser afsat uden for en isrand. Jamen, et jordartskort er - bør være - et litologisk kort, og "extramarginale dannelser" er ikke en lithologisk betegnelse, men en tolkning.

Ved at tolke sandlagene vest for "Hovedopholdslinien" som "extramarginale dannelser" har man vildført generationer af danskere til at lave den smukke lille cirkelslutning, at jordartskortet viser, at isen under sidste istid ikke kom længere end til "Hovedopholdslinien". I det "ærlige jordartskort" har smeltevandssand smeltevandssandets farve, uanset om det ligger øst eller vest for "Hovedopholdslinien" og så forsvinder den ganske!

\section{Isen var længere ude}

Noget andet er så, at der er flere ting, der taler for, at isen faktisk var længere ude end til "Hovedopholdslinien" under sidste istid. Der er dødishullerne. Sunds Sø er et af dem, som er så stort, at det er vanskeligt at forestille sig en isklump kommet så langt ud på hedesletten, med mindre den er blevet efterladt af et smeltende isdække.

Kurt Kjær, Michael Houmark og Niels Richard påviser i en artikel (Boreas, 2003), at de flydelinier $i$ isen, som kan udledes af landskabets strukturer heller ikke passer med den isgrænse, som "Hovedopholdslinien definerer. Der kommer en mere uddybende diskussion af "Hovedopholdslinien" i Geologisk Tidsskrift i 2006. Se også diskussionerne om det alternative paradigme for istidslandskabets dannelse på www.geologiskesevaerdigheder.dk

Denne artikel har vœret bragt i VARV nr. 3. 2005.

\section{Læs mere på:} www.geologiskesevaerdigheder.dk 